\title{
High-K volcanism in the Afyon region, western Turkey: from Si-oversaturated to Si-undersaturated volcanism
}

\author{
Cüneyt Akal · Cahit Helvacı · Dejan Prelević · \\ Paul van den Bogaard
}

Received: 11 August 2011/Accepted: 30 June 2012/Published online: 28 August 2012

(C) The Author(s) 2012. This article is published with open access at Springerlink.com

\begin{abstract}
Volcanic rocks of the Afyon province (eastern part of western Anatolia) make up a multistage potassic and ultrapotassic alkaline series dated from 14 to $12 \mathrm{Ma}$. The early-stage Si-oversaturated volcanic rocks around the Afyon city and further southward are trachyandesitic volcanic activity (14.23 $\pm 0.09 \mathrm{Ma})$. Late-stage Si-undersaturated volcanism in the southernmost part of the Afyon volcanic province took place in three episodes inferred from their stratigraphic relationships and ages. Meliliteleucitites $(11.50 \pm 0.03 \mathrm{Ma})$, spotted trachyandesites, tephryphonolites and lamproites $(11.91 \pm 0.13 \mathrm{Ma})$ formed in the first episode; trachyandesites in the second episode and finally phonotephrites, phonolite, basaltic trachyandesites and nosean-bearing trachyandesites during the last episode. The parameter $Q$ [normative $q$ - $(\mathrm{ne}+\mathrm{lc}+\mathrm{kls}+\mathrm{ol})$ ] of western Anatolia volcanism clearly decreased southward with time becoming zero in the time interval 10-15 Ma. The magmatism experienced a sudden change in the extent of Si saturation after $14 \mathrm{Ma}$, during late-stage volcanic
\end{abstract}

Electronic supplementary material The online version of this article (doi:10.1007/s00531-012-0809-9) contains supplementary material, which is available to authorized users.

\section{Akal $(\bowtie) \cdot$ C. Helvacı}

Mühendislik Fakültesi Jeoloji Mühendisliği Bölümü,

Dokuz Eylül Üniversitesi, 35160 Tinaztepe, Buca,

Izmir, Turkey

e-mail: cuneyt.akal@deu.edu.tr

\section{Prelević}

Institute for Geosciences, Earth System Science Research Centre, University of Mainz, Becherweg 21,

55099 Mainz, Germany

P. van den Bogaard

IFM-GEOMAR, Wischhofstr. 1-3, 24148 Kiel, Germany activity of Afyon volcanic province at around $12 \mathrm{Ma}$, though there was some coexistence of Si-oversaturated and Si-undersaturated magmas during the whole life of Afyon volcanic province.

Keywords Afyon volcanic province $\cdot$ High-K volcanism · Western Anatolia $\cdot$ Lamproite $\cdot$ Leucitite

\section{Introduction}

In the Tertiary western Anatolia, Turkey and the surrounding areas have experienced extensive igneous activity. The magmatism was spatially and temporally associated with Late Cretaceous-Cenozoic convergence of Africa-derived terrains with Eurasia, which resulted in the progressive closure of oceanic basins and series of collisional events. These events resulted in the internal imbrication of the Menderes Massif block and the southward overthrusting of the Lycian nappes (Fig. 1), eventually leading to late Miocene extensional tectonics and Menderes Massif uplift (Şengör et al. 1984; Yılmaz et al. 2000; Işık et al. 2004; Ring and Collins 2005; Çemen et al. 2006; Westaway 2006; Glodny and Hetzel 2007; Prelević et al. 2012). During the postcollisional period, potassic and ultrapotassic magmas were produced along with calc-alkaline and crust-derived magmas in the western Anatolia (Bozkurt 2001, 2003; Bozkurt and Mittwede 2005; Şengör and Y1lmaz 1981; Şengör et al. 1985).

One of the most interesting features of the western Anatolian volcanism is the geochemical diversity of the volcanic rocks, which is spatially and temporally controlled. Variable $\mathrm{K}$-enrichment, different extent of Si-saturation and extremely variable isotopic and trace element compositions are clearly coupled with southward younging of the volcanism (Francalanci et al. 2000; Dilek and Altunkaynak 2007; 


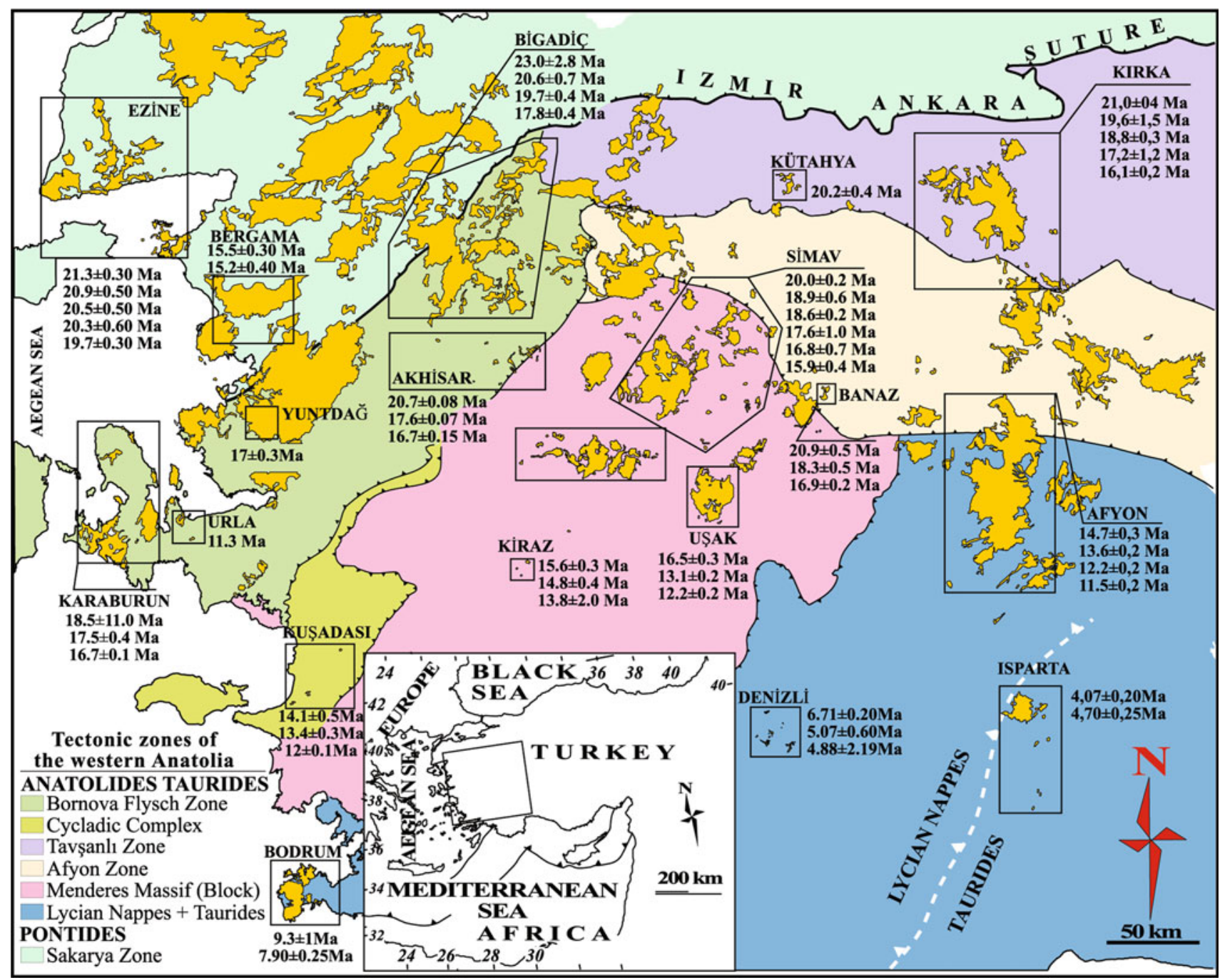

Fig. 1 Distribution of Neogene to Quaternary potassic-ultrapotassic volcanic rocks within the western Anatolia. Tectonic zones of western Anatolia are from Okay and Tüysüz (1999). Distribution of the volcanic rocks is modified from MTA $1 / 500,000$ scale geological map of Turkey. The summarized ages are from Borsi et al. (1972), Besang et al. (1977), Pişkin (1980), Sunder (1980), Paton (1992), Ercan et al.

Helvac1 et al. 2009; Ersoy et al. 2010a; Prelević et al. 2012). The genesis and geodynamic implications of this magmatism are still a matter of debate, but large-scale mantle-source heterogeneity in its petrogenesis is widely accepted. North to south variations in the geochemical characteristics are believed to be the response to rolling back of Aegean slab, movement of the slab window, a collapse of the overthickened Menderes Massif or as combination of these events (e.g., Şengör et al. 1985; Spakman et al. 1988; Seyitoğlu and Scott 1996; Wortel and Spakman 2000; Rimmelé et al. 2003; Faccenna et al. 2004; Glodny and Hetzel 2007; van Hinsbergen et al. 2010; Biryol et al. 2011; Prelević et al. 2012).
(1996), Seyitoğlu et al. (1997), Aldanmaz et al. (2000), Ercan et al. (2000), Helvacı and Alonso (2000), Robert and Montigny (2001), Erkül et al. (2005), Purvis et al. (2005), Innocenti et al. (2005), Westaway et al. (2005), Ersoy et al. (2008), Helvac1 et al. (2009), Ersoy et al. (2010b) and Karaoğlu et al. (2010)

Time and space distribution of volcanism demonstrate robust correlation with extent of silica saturation. Silica saturation is traditionally used to define distinct parental magmas and evolutional trends of basaltic melts (Yoder and Tilley 1962), implying that no single magma under equilibrium conditions could give rise to both oversaturated and undersaturated basaltic trends. Therefore, silica saturation of volcanic rocks may be source controlled and has genetic significance in tracing the geodynamic attribution, especially in postcollisional environments. In the case of western Anatolian volcanism, it is shown that the parameter $Q$ [normative $q$-(ne $+\mathrm{lc}+\mathrm{kls}+\mathrm{ol}$ )] that is used as a measure of $\mathrm{Si}$ saturation clearly decreases 
Fig. 2 a $\mathrm{Na}_{2} \mathrm{O}+\mathrm{K}_{2} \mathrm{O}$ versus $\mathrm{SiO}_{2}$ diagram from Le Bas et al. (1986) for volcanic rocks from the study area. The dashed line approximates the transition between alkaline and subalkaline series after Irvine and Baragar (1971). Melilite leucitite and lamproite analyses are from Akal (2003, 2008, respectively). b Si-saturation index (normative

$Q$-(ne $+\mathrm{lc}+\mathrm{kls}+\mathrm{ol})$;

Peccerillo 2003) versus $\mathrm{MgO}$ of Afyon lavas (this study). c Si-saturation index [normative $Q$-(ne $+\mathrm{lc}+\mathrm{kls}+\mathrm{ol})]$ versus age of western Anatolian lavas and early-stage lavas of Afyon Volcanics. Data from Agostini et al. $(2008,2010)$, Akal and Helvac1 (2000), Akal (2003, 2008), Alıc1 et al. (1998), Aydar et al. (1998), Çoban and Flower (2006), Çoban and Flower (2007), Ersoy et al. (2008, 2010a, b), Francalanci et al. (2000), Karaoğlu et al. (2010), Kumral et al. (2006)
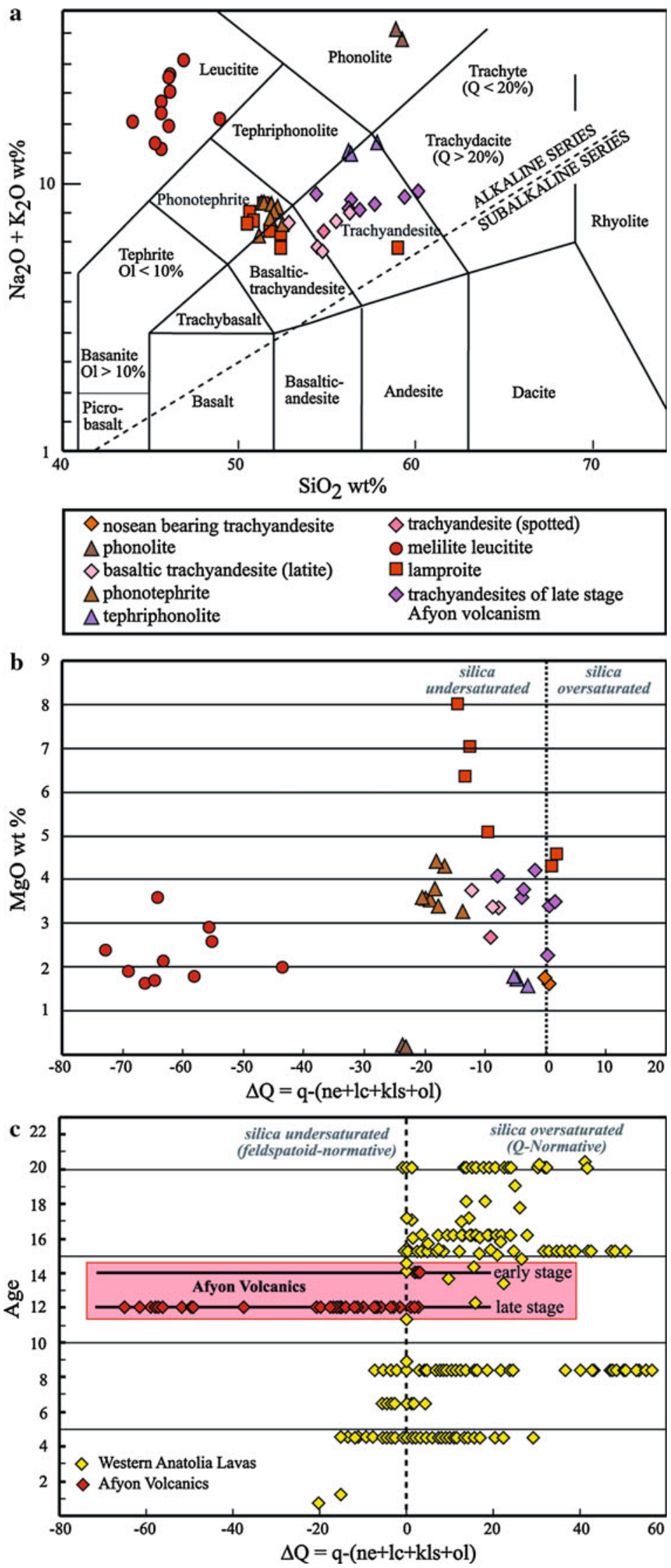
southward with age (Fig. 2a); degree of Si saturation is around zero in the time interval $10-15 \mathrm{Ma}$ in the Afyon region (Fig. 2b). More precise knowledge of the time interval over which this change happened, and the manner of this switch from Si oversaturation to Si undersaturation is therefore essential. From that point of view, the stratigraphic framework and age distributions of the volcanic products in Afyon area have a special importance.

This paper is the first part of a comprehensive study of rocks from the southern part of Afyon volcanic province. Here, we present a detailed volcanic stratigraphy together with $\mathrm{Ar}-\mathrm{Ar}$ crystallization age determinations of minerals belonging to different volcanic stages and episodes from the Afyon volcanic province. Our aim is to trace the timing and the manner of the switch from Si-oversaturated to Si-undersaturated magmas. Our new data and data from previous studies provide evidence for the sudden change in the extent of Si saturation after $14 \mathrm{Ma}$. At approximately $12 \mathrm{Ma}$, coexistence of Si-oversaturated and Si-undersaturated magmas is indicated for volcanic rocks across the whole of the Afyon volcanic province.

\section{Geological setting of Afyon province}

The study area is located south of the Afyon city, classically considered a part of southward trending Kurka-AfyonIsparta alkaline volcanic district (Figs. 1, 2, 3). It occurs between Köroğlu caldera (Aydar et al. 1996, 2003) that collapsed at $\sim 15 \mathrm{Ma}$ (Aydar et al. 1998; Prelević et al. 2012) in the north and Isparta-Gölcuik volcanic area in the south where volcanism began with lamproites around $4 \mathrm{Ma}$ and terminated with trachytic rocks at the Gölcük volcano, at around $10 \mathrm{ka}$ (Lefèvre et al. 1983; Floyd et al. 1998; Prelević et al. 2012).

The Afyon volcanics unconformably overlie Paleozoic and Mesozoic basement of the Afyon Metamorphic Zone and Tauride Belt, which belongs to the Anatolide-Tauride Block of Turkey (Figs. 4, 5). The various volcanic products cover and intrude the sedimentary formations of the northeastern portion of the western Tauride Belt, which comprise the Geyik Dağ Unit and the Bozkır Unit (Özgül 1984). The Geyik Dağ Unit is the autochthon of the Central Taurides and consists of platform-type sediments of Lower Paleozoic basement (Cambrian and Ordovician) and a Mesozoic-Lower Tertiary made up largely of carbonates (Göncüoğlu 1997; Göncüoğlu and Kozlu 2000; Erdoğan et al. 2004; Güngör 2006; Gürsu and Göncüoğlu 2006, 2007). The Bozkır Unit corresponding to the BeyşehirHoyran-Hadim nappes defined by Poisson et al. (1984) forms a mélange of pelagic sediment, spilite, diabase and ultramafic blocks of various ages between Upper Triassic and Upper Cretaceous.

\section{Analytical methods}

Major elements of representative volcanic rock samples from the Afyon volcanic province were analyzed by X-ray fluorescence spectrometry (XRF) with an ARL8420 XRF at the Geochemical Laboratories of Keele University, England, calibrated against international and internal standards. Details of methods, accuracy and precision are given in Floyd and Castillo (1992).

${ }^{40} \mathrm{Ar} /{ }^{39} \mathrm{Ar}$ incremental heating experiments were conducted on 3 samples of phlogopite and leucite phenocryst separates at the IFM-GEOMAR Tephrochronology Laboratory. After crushing and sieving, the particles were handpicked from the 100-300- $\mu$ m-size fraction. Resulting mineral separates and chips were cleaned using an ultrasonic disintegrator. Phenocrysts were then etched in $15 \%$ hydrofluoric acid for $10 \mathrm{~min}$. Samples were neutron irradiated at the $5 \mathrm{MW}$ reactor of the GKSS Reactor Center (Geesthacht, Federal Republic of Germany), with crystals and matrix chips in aluminum trays and irradiation cans wrapped in $0.7-\mathrm{mm}$ cadmium foil. Samples were stepheated by laser. Purified gas samples were analyzed using a MAP 216 noble gas mass spectrometer. Raw mass spectrometer peaks were corrected for mass discrimination, and background and blank values determined every fifth analysis. The neutron flux was monitored using TCR sanidine (Taylor Creek Rhyolite $=27.92 \mathrm{Ma}$; Dalrymple and Duffield 1988) and internal standard SAN6165 (0.470 Ma; Van den Bogaard 1995). Vertical variations in $\mathbf{J}$ values were quantified by a cosine function fit. Lateral variations in $\mathrm{J}$ were not detected. Corrections for interfering neutron reactions on $\mathrm{Ca}$ and $\mathrm{K}$ are based on analyses of optical grade $\mathrm{CaF}_{2}$ and high-purity $\mathrm{K}_{2} \mathrm{SO}_{4}$ salt crystals that were irradiated together with the samples. Ages derived from step-heating analyses are based on plateau portions of the age spectra. Plateau regions generally comprise $>50 \%$ of the ${ }^{39} \mathrm{Ar}$ released and more than three consecutive heating steps that yield the same ages (within $2 \sigma$ error).

Results of age determinations are presented in Table 2, and complete age spectra are presented in Appendix 1 of Electronic supplementary material. For all measurements, we produced acceptable plateaus larger than $50 \%$, and in most cases larger than $80 \%$. Plateau ages range from 14.7 to $11 \mathrm{Ma}$.

\section{Results and discussion}

The bulk rock major element compositions for the representative samples are reported in Table 1. Two subgroups are recognized according to their silica saturation [normative $q$-(ne $+\mathrm{lc}+\mathrm{kls}+\mathrm{ol})]$ : silica saturated to oversaturated ( $Q$-normative), and silica undersaturated 
(feldspathoid-normative). The $Q$-normative rocks are lamproites, basaltic trachyandesites and trachyandesites, whereas feldspathoid-normative rocks span a large range from phonotephrites, melilite-leucitites, latites and phonolites (Fig. 2a, b). Table 3 shows a summary of the petrographical and geochemical characteristics of the volcanic episodes around southern side of Afyon volcanic province.

Potassium enrichment is one of the most striking features of Afyon volcanics. A number of high-MgO (5\%) volcanic types are also $\mathrm{K}$-enriched $\left(>3 \% \mathrm{~K}_{2} \mathrm{O}\right)$, indicating that the potassium enrichment is related to the mantle processes. The geochemical data are plotted on the total alkali versus silica diagram (Le Bas et al. 1986) with alkaline and subalkaline dividing line defined by Irvine and Baragar (1971) (Fig. 2a). In this scheme, the Afyon volcanic province rock samples, taken from massive rocks such as lava flows and domes, exhibit an alkaline major oxide trend with their $\mathrm{Na}_{2} \mathrm{O}-2<\mathrm{K}_{2} \mathrm{O}$ contents and range in composition from leucitite, phonolite, phonotephrite, basaltic trachyandesite (shoshonite) to trachyandesite (latite). On the other hand, low $\mathrm{MgO}$ contents in the samples do not support their primary character, being evolved due to fractionation and/or assimilation. $\mathrm{TiO}_{2}$ contents of the all samples are $<1.4 \mathrm{wt} \%$, which are characteristics of orogenic alkaline volcanic rock suites, as described by Thompson (1997) and Robert et al. (1992).

The volcanic and volcaniclastic products of the high K-alkaline eruptions cover approximately $200 \mathrm{~km}^{2}$ (Figs. 3, 4). Based on the detailed stratigraphic and age determination studies of the volcanic rocks in the study area, it is possible to divide them into two main volcanic stages (early stage and late stage) in which lavas and volcanoclastic successions have been observed (Fig. 4).

\section{Early-stage volcanism}

Early-stage volcanism of the Afyon volcanic province is represented by widespread trachyandesitic rocks and their volcaniclastic products, underlain by the sedimentary formations of the Tauride Belt. Around and within Afyon city and further southward, several variably sized trachyandesitic lava domes, plugs, subvolcanic stocks and laterally discontinuous stubby lava flows cut their pyroclastic successions. The ages of the lavas are reported by Besang et al. (1977): Trachyte from Kılıçaslan-south of Afyon is $14.75 \pm 0.3 \mathrm{Ma}$, and latite-andesite from the west of Afyon is $13.6 \pm 0.2 \mathrm{Ma}$ (Fig. 2). Our age determination of a trachyandesitic lava dome, near Kayadibi location, using mica crystals (Table 2)

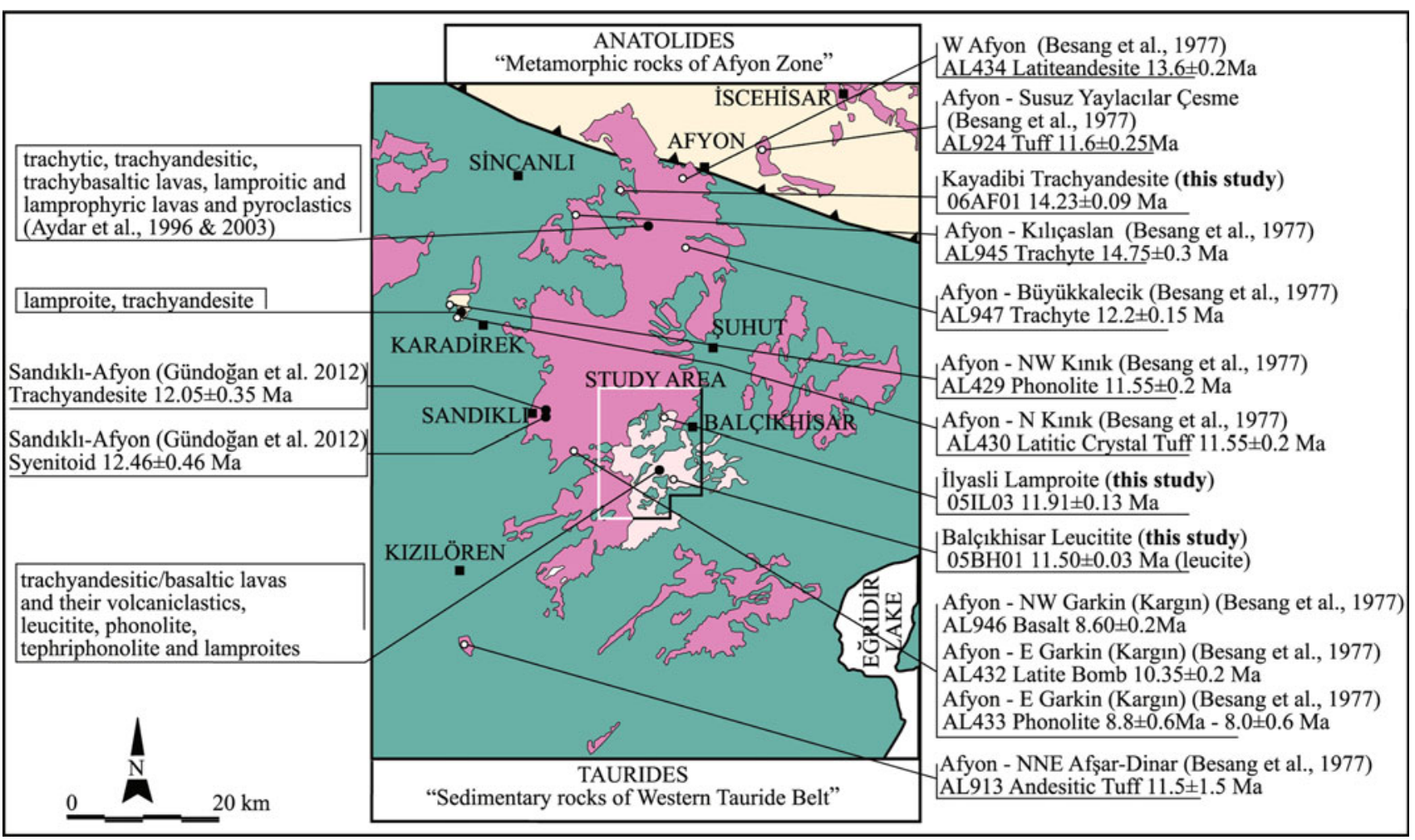

Fig. 3 Geological sketch map, main rock types and ages of the Afyon calc-alkaline-alkaline volcanic district (western Anatolia). Dark lines indicate tectonic zones of Anatolide-Tauride Block composed of
Afyon Zone of Anatolides and western Tauride Belt of Taurides beneath the province (Okay and Tüysüz 1999). Map is modified from MTA 1/500,000 scale geological map of Turkey 


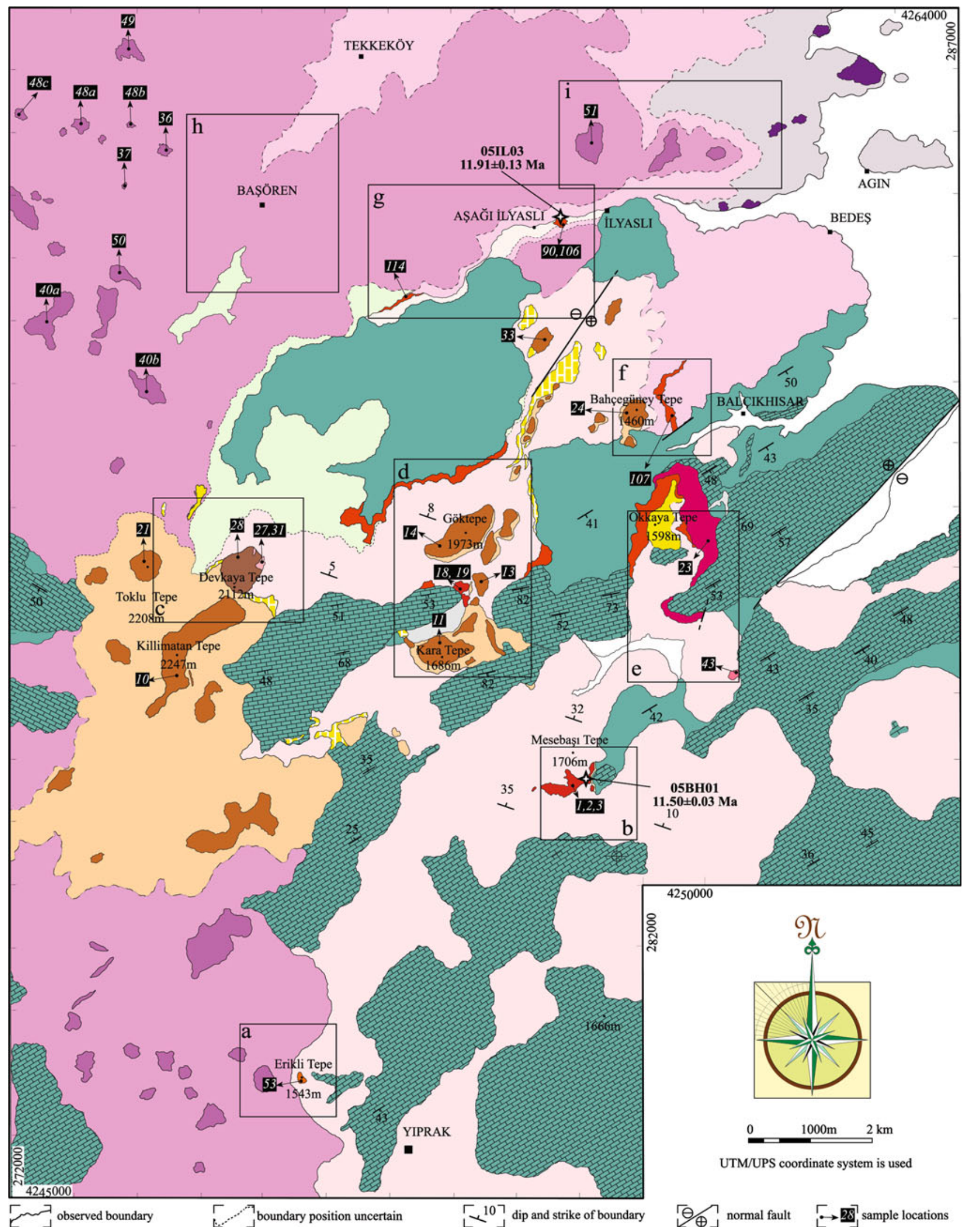

Fig. 4 Geological map of high-potassium volcanics and their volcaniclastics in the southern part of the Afyon volcanic province. The stratigraphic columnar sections and explanations of the each small area marked on the map are given in Fig. 5 
shows $14.23 \pm 0.09 \mathrm{Ma}$ (mica age from the sample "06AF01"). The early-stage products of the trachyandesitic volcanic activity around Balçkhisar town and the Killimatan Tepe location were partly covered by leucitite volcaniclastic deposit of the late stage (Fig. 4b-f).

\section{Late-stage volcanism}

Products of the late-stage volcanism are divided into three episodes based on their stratigraphic relationships and age data. Melilite-leucitites, spotted trachyandesites, tephryphonolites and lamproites are first episode; trachyandesites are second episodes, and phonotephrites, phonolite, basaltic trachyandesites and nosean-bearing trachyandesites are last episode (Fig. 4).

\section{First episode of late-stage volcanism}

Volumetrically small lava domes and flows of the firstepisode volcanic activity cover sediments of the Tauride
Belt such as limestone, pebblestone, siltstone and shale and are mainly overlain by leucitite volcaniclastic deposits.

Melilite-Leucitites were emplaced as domes and short lava flows $(11.50 \pm 0.03 \mathrm{Ma}$; leucite crystals of the sample “05BH01”). At Meşebaş1 and Göktepe locations (Fig. 4b, d), the dome-like emplacement mode and contact relationship with basement rock of the leucitite bodies are well observed. Spotted trachyandesite is exposed as a smallscale dome-shaped body, which crops out $4 \mathrm{~km}$ to the south of the Balçıkhisar town (Fig. 4e). The outcrop is about $150 \mathrm{~m} \times 100 \mathrm{~m}$ over the basement limestones. The grayish trachyandesite displays $2-10$-cm-thick flow bands orientated at high angles to vertical. These lavas are easily distinguished by their spotted patterns, which are lighter than the rest of matrix (Fig. 6b). The spots represent spherical structures $5-10 \mathrm{~mm}$ in diameter. The flow foliation and mineral lineation is defined by the long axes of hornblende phenocrysts in a glassy matrix (Fig. 7b). Tephriphonolite lava flows located $2 \mathrm{~km}$ south of the Balçıkhisar at the Okkakaya Tepe are exposed in an area of
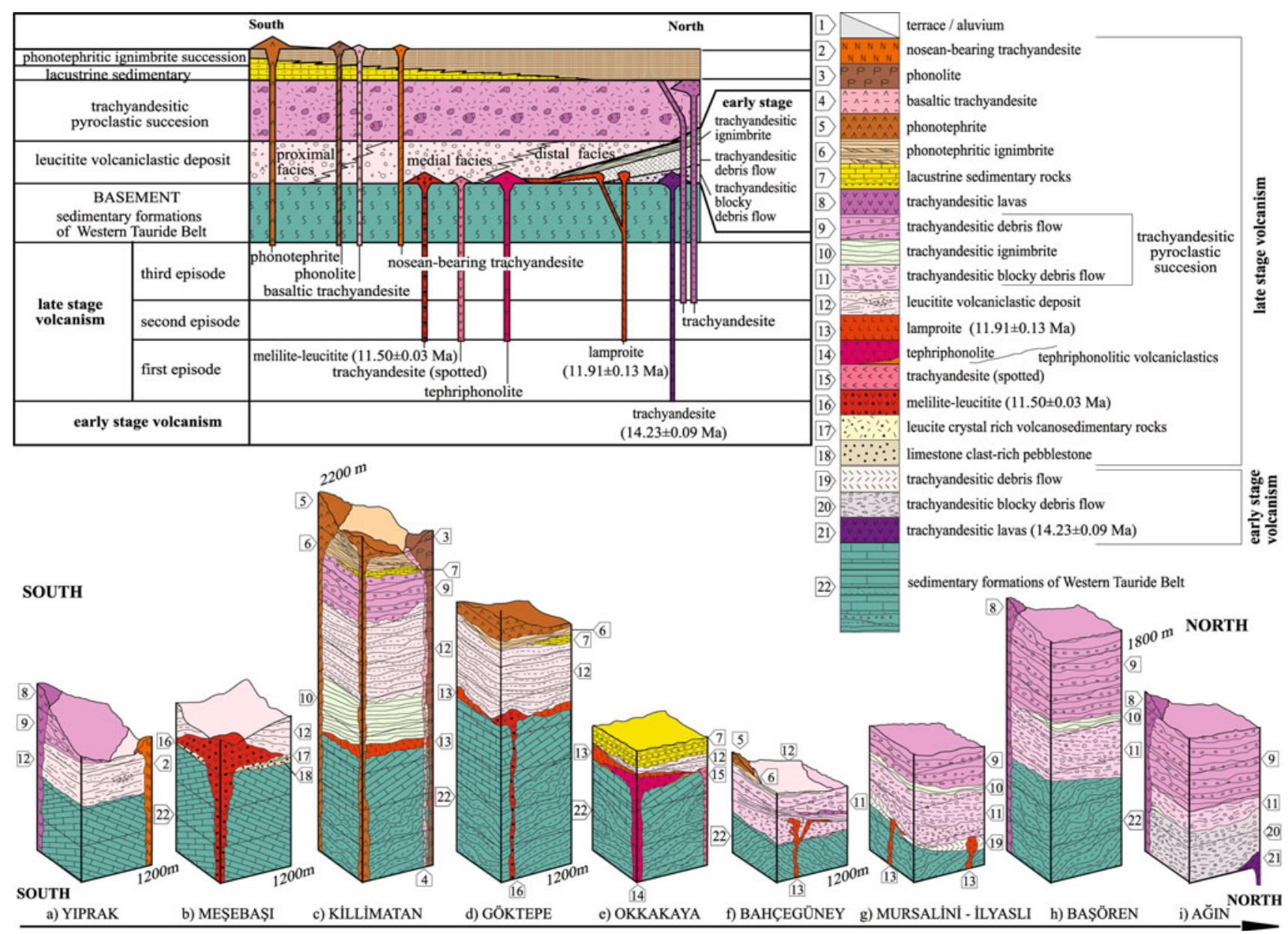

Fig. 5 Generalized stratigraphic section of southern part of the Afyon volcanic province. Stratigraphic correlations of the volcanic succession, which overlies sedimentary formation of the Tauride Belt. Section localities are shown in Fig. 4 


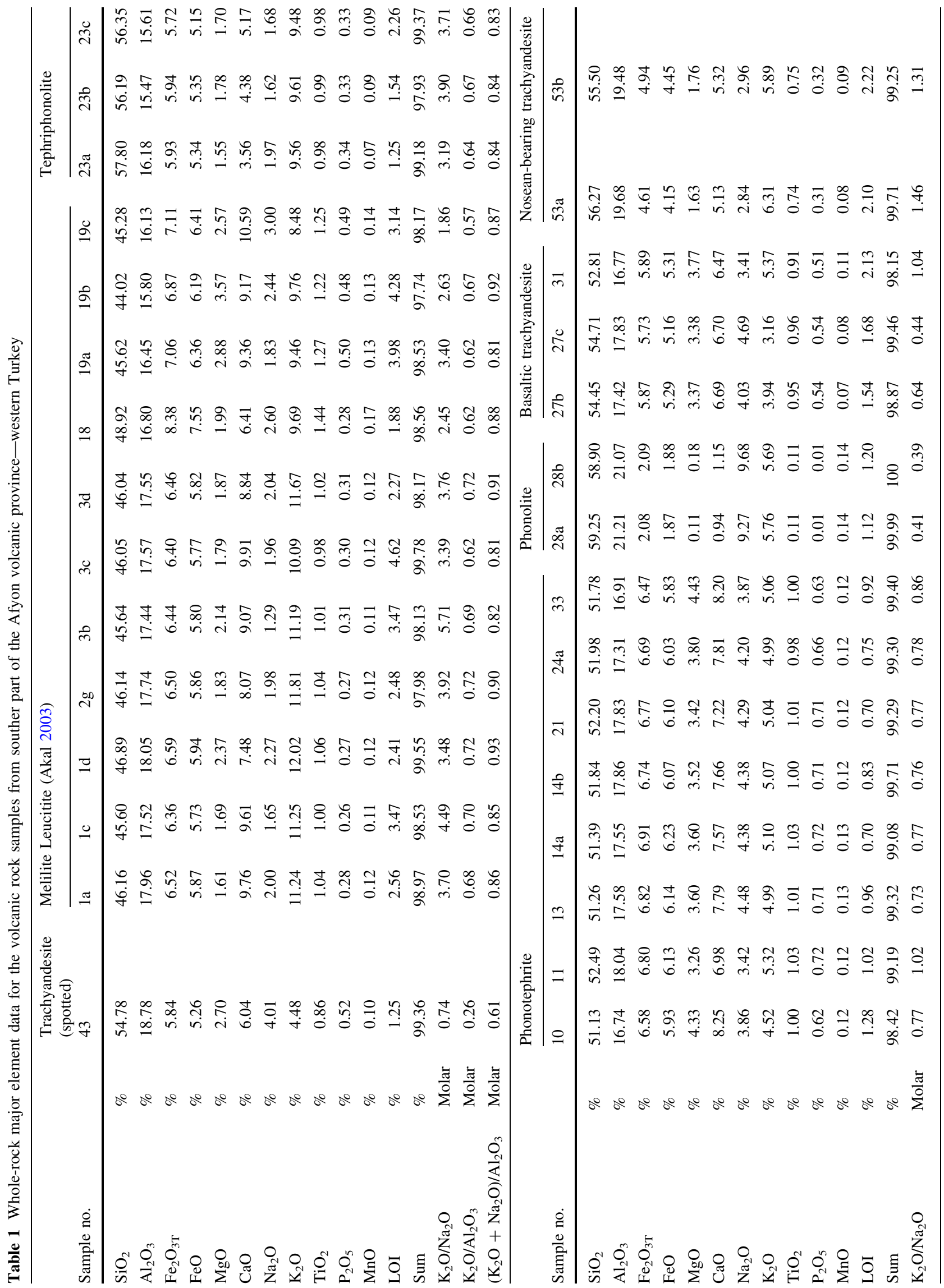




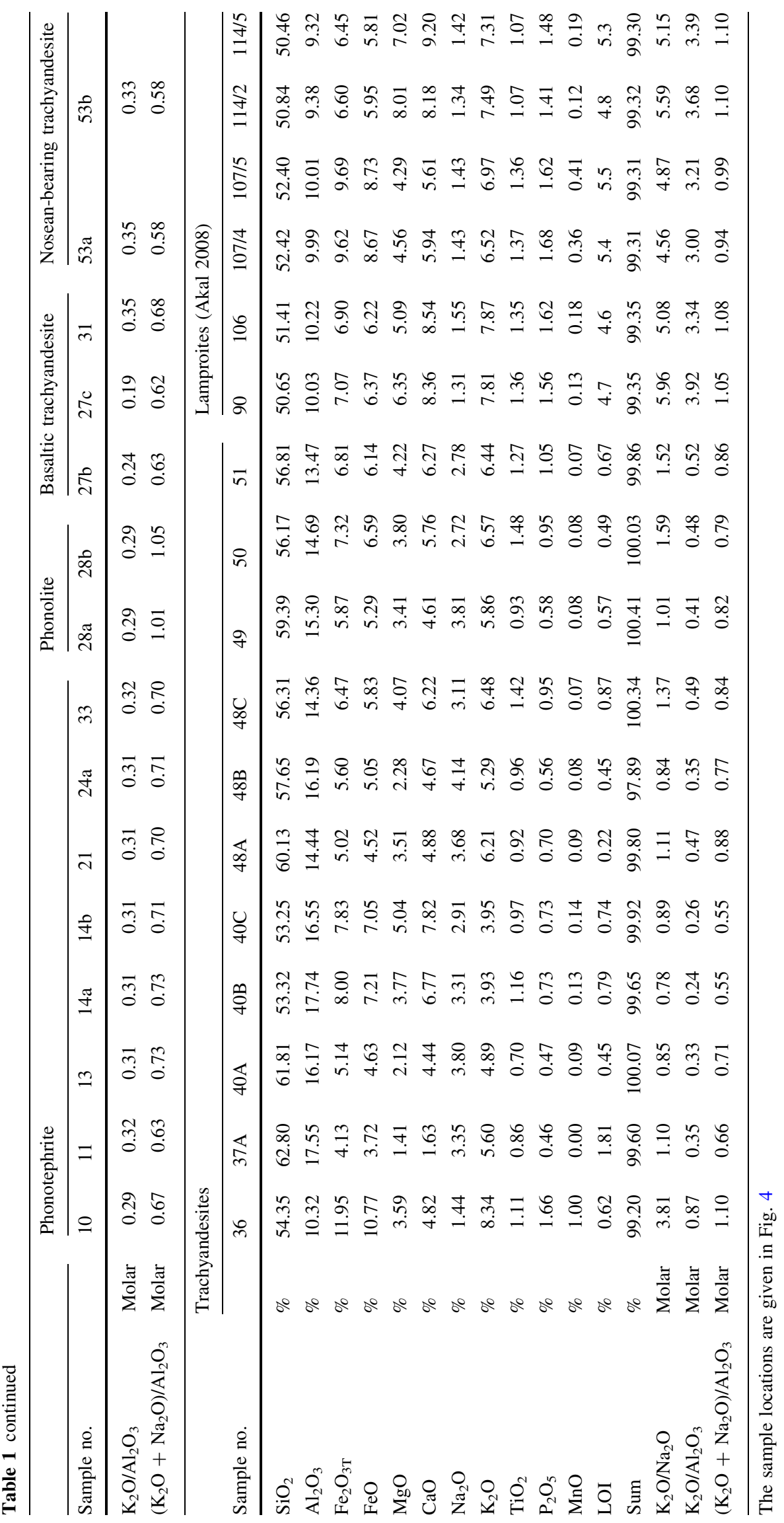


Table $2{ }^{40} \mathrm{Ar} /{ }^{39} \mathrm{Ar}$ dating of volcanic rocks and cumulates from Afyon volcanic province

\begin{tabular}{|c|c|c|c|c|c|c|c|c|}
\hline Sample & $\begin{array}{l}\text { Coordinates } \\
\text { (UTM/UPS) }\end{array}$ & Locality & Rock type & Mineral type & $\begin{array}{l}\text { Plateau } \\
\text { age (Ma) }\end{array}$ & Error $\pm(2 \sigma)$ & MSWD & ${ }^{39} \mathrm{Ar}(\%)$ \\
\hline 06AF01 & $\begin{array}{l}36 \text { S } 0274049 \\
\text { E } 4289520\end{array}$ & Kayadibi & Trachyandesite & Mica & 14.23 & 0.09 & 1.10 & 76.7 \\
\hline 05IL03 & $\begin{array}{l}36 \text { S } 0279493 \\
\text { E } 4259632\end{array}$ & İlyasli & Lamproite & Phlogopite & 11.91 & 0.13 & 0.66 & 67.4 \\
\hline 05BH01 & $\begin{array}{l}36 \mathrm{~S} 0282567 \\
\text { E } 4254578\end{array}$ & Balçıkhisar & Melilite Leucitite & Leucite & 11.50 & 0.03 & 2.6 & 60.8 \\
\hline
\end{tabular}

about $0.75 \mathrm{~km}^{2}$. They are up to $0.5 \mathrm{~km}$ in width and $2 \mathrm{~km}$ long with a total flow thickness of up to $90 \mathrm{~m}$. Tephriphonolitic volcanism has produced a small volcaniclastic deposit that is observed as a thin layer in the southern part of the investigation area (Fig. 6c). The tephriphonolitic volcaniclastic deposit comprises crystal fragment-rich volcaniclastic sandstone, which is divided into two different horizons by a paleosol. At the lower part of phlogopite and pyroxene crystal fragment-rich volcanic sandstone (4 $\mathrm{m}$ thick), well-developed low-angle cross-bedding can be easily distinguished. The tephriphonolitic volcaniclastic deposits are covered by lava flows of tephriphonolite, and leucitite volcaniclastic deposits (Fig. 4e) plus eruptive volcaniclastic products of trachyandesitic volcanism (second episode) overlying the leucitite volcaniclastic deposit.

The near-surface emplacement and relatively weak subaerial eruptions of lamproite magma produce lava flows, dykes and dome structures, inducing variation in volume and textural features. As seen in Fig. $4 \mathrm{~d}-\mathrm{g}$, the lamproites are hosted and underlain by Mesozoic-to-Tertiary sedimentary rocks of the Tauride Belt. The outcrops are mainly covered by the leucitite volcaniclastic deposit and the trachyandesitic pyroclastic succession. Around Balçıkhisar and İlyaslı, lamproite intrudes into early-stage products of the trachyandesitic pyroclastic succession (Figs. 4c-g, 5).

Table 3 Textural and mineralogical compositions of the volcanic rocks

\begin{tabular}{|c|c|c|c|c|c|c|c|c|c|}
\hline \multirow[t]{2}{*}{ Rock type } & \multirow{2}{*}{$\begin{array}{l}\text { Lithology } \\
\text { and volcanic } \\
\text { facies }\end{array}$} & \multirow[t]{2}{*}{ Texture } & \multirow{2}{*}{$\begin{array}{l}\text { The extent of } \\
\text { Si saturation } \\
q-(\text { ne }+\mathrm{lc}+ \\
\mathrm{kls}+\mathrm{ol})\end{array}$} & \multirow[t]{2}{*}{$\mathrm{MgO}(\%)$} & \multirow{2}{*}{$\begin{array}{l}\mathrm{K}_{2} \mathrm{O} / \\
\mathrm{Na}_{2} \mathrm{O}\end{array}$} & \multicolumn{4}{|c|}{ Mineral assemblage } \\
\hline & & & & & & Phenocryst & $\begin{array}{l}\text { Micro- } \\
\text { phenocryst }\end{array}$ & Groundmass & Xenoliths \\
\hline Melilite Leucitite & $\begin{array}{l}\text { Dome, lava } \\
\text { flow }\end{array}$ & Fig. 8a & -72 to -43 & $1.61-2.88$ & $1.90-5.7$ & $\mathrm{cpx}, \mathrm{pl}$, let & $\begin{array}{l}\text { cpx, pl, let, ne, } \\
\text { Ba-feld, mel, ap, }\end{array}$ & $\begin{array}{l}\text { cpx, pl, let, } \\
\text { ne, mlt, ap }\end{array}$ & \\
\hline $\begin{array}{l}\text { Trachyandesite } \\
\text { (spotted) }\end{array}$ & Dome & Fig. $8 \mathrm{~b}$ & -9.17 & 2.70 & 0.74 & hbl, pl & $\begin{array}{l}\text { cpx, hbl, sa, pl, } \\
\text { ap, }\end{array}$ & $\begin{array}{l}\text { cpx, phl, pl, } \\
\text { ap }\end{array}$ & \\
\hline Tephriphonolite & Lava flow & Fig. $8 \mathrm{c}$ & -5 to -3 & $1.55-1.78$ & $3.2-3.9$ & cpx, sa & $\begin{array}{l}\text { cpx, phl, sa, nsn, } \\
\text { ap }\end{array}$ & $\begin{array}{l}\text { cpx, pl, sa, } \\
\text { ap }\end{array}$ & \\
\hline Trachyandesite & Dome & Fig. $8 \mathrm{~d}$ & -3 to 1.5 & $1.41-4.22$ & $0.8-3.8$ & $\begin{array}{l}\text { cpx, bt, sa, } \\
\text { pl, sph }\end{array}$ & cpx, bt, sa, pl, ap & $\begin{array}{l}\text { cpx, bt, sa, } \\
\text { pl }\end{array}$ & $\mathrm{sph}, \mathrm{qtz}$ \\
\hline Lamproite & Dyke, dome & Fig. $8 \mathrm{e}$ & -14 to 1.8 & $4.29-8.01$ & $4.5-5.9$ & $\begin{array}{l}\text { cpx, rcht, } \\
\text { phl, sa, } \\
\text { ol }\end{array}$ & cpx, rcht, phl, ap & cpx, rcht, ap & cpx \\
\hline Phonotephrite & $\begin{array}{c}\text { Dome, dyke, } \\
\text { lava flow }\end{array}$ & Fig. $8 \mathrm{f}$ & -20 to -14 & $3.42-4.43$ & $0.7-1$ & $\begin{array}{l}\text { cpx, hbl, } \\
\text { bt/phl, pl }\end{array}$ & $\begin{array}{l}\text { cpx, hbl, bt/phl pl, } \\
\text { sa, ap }\end{array}$ & $\mathrm{cpx}, \mathrm{pl}$ & qtz, ol \\
\hline Phonolite & $\begin{array}{c}\text { Dome, rubble } \\
\text { lava flow }\end{array}$ & Fig. $8 \mathrm{~g}$ & -23 to -24 & $0.11-0.18$ & 0.4 & sa & $\mathrm{cpx}, \mathrm{sa}, \mathrm{nsn}$ & sa, ap & \\
\hline $\begin{array}{l}\text { Basaltic } \\
\text { Trachyandesite }\end{array}$ & Dome & Fig. $8 \mathrm{~h}$ & -12 to -8 & $3.37-3.77$ & $0.4-1$ & $\begin{array}{l}\text { cpx, hbl, } \\
\text { bt, }\end{array}$ & $\begin{array}{l}\text { cpx, hbl, bt, sa, pl, } \\
\text { ap }\end{array}$ & $\begin{array}{l}\text { cpx, hbl, bt, } \\
\text { pl, sa, nsn }\end{array}$ & \\
\hline $\begin{array}{l}\text { Nosean-bearing } \\
\text { Trachyandesite }\end{array}$ & Dome & Fig. $8 \mathrm{i}$ & 0 & $1.63-1.76$ & $1.3-1.5$ & cpx, hbl, pl & $\begin{array}{l}\text { cpx, hbl, sa, pl, } \\
\text { nsn, ap }\end{array}$ & $\mathrm{pl}$, ap, nsn & \\
\hline
\end{tabular}

ap apatite, Ba-feld barium feldspar, bt biotite, $c p x$ clinopyroxene, let leucite, $h b l$ hornblende, mel melilite, mlt melanite, ne nepheline, $n s n$ nosean, ol olivine, $p h l$ phlogopite, $p l$ plagioclase, $q t z$ quartz, $r c h t$ richterite, $s a$ sanidine, $s p h$ sphene 

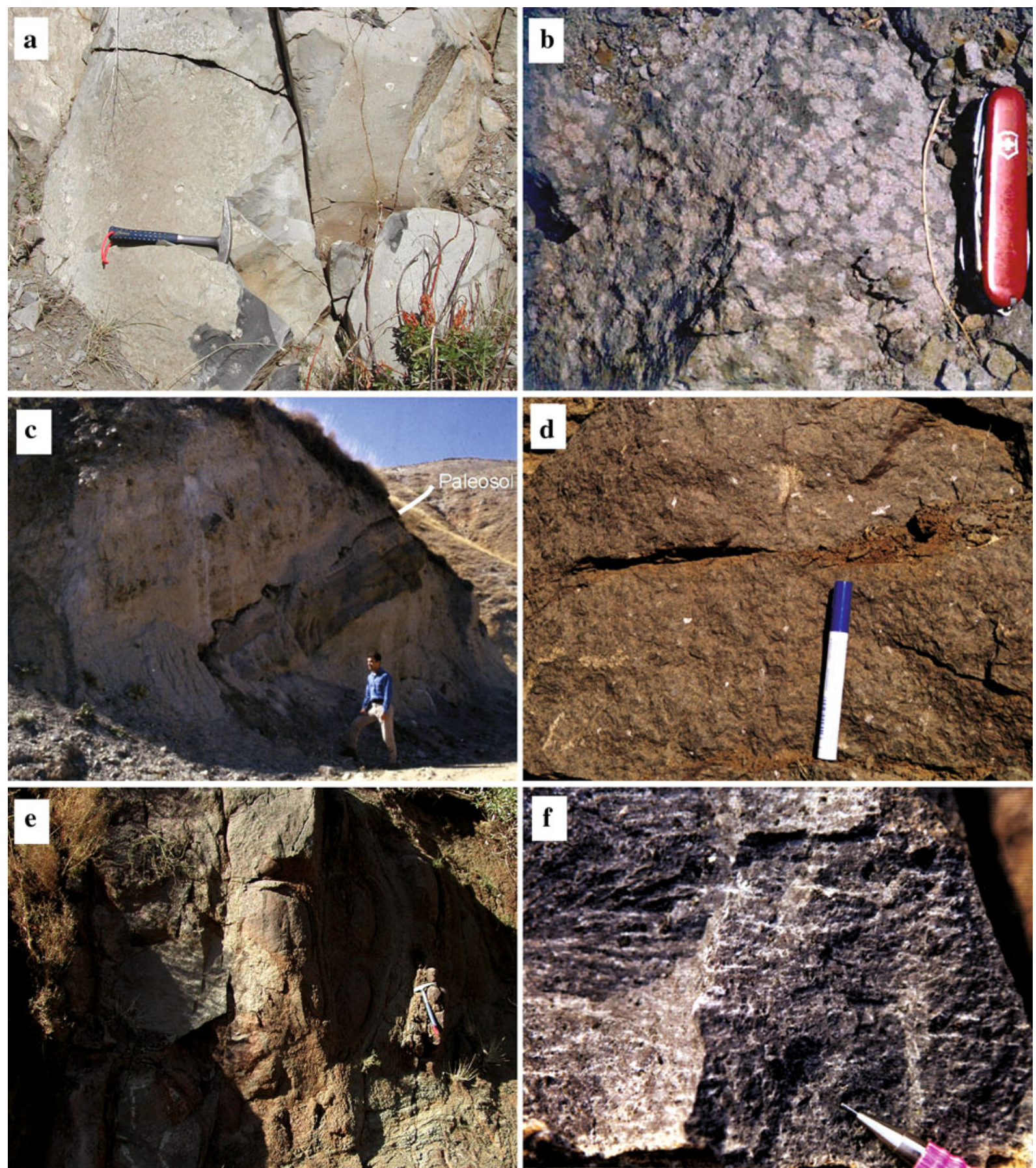

Fig. 6 Macroscopic properties of the volcanic rocks; a gray-dark gray-colored leucitite lavas and euhedral leucite phenocryst in the leucitite lavas at Meşebaşı location, $\mathbf{b}$ spotted patterns are observed in all parts of the lava, but spots are most pronounced at the lava surface, due to the atmospheric weathering process, c gray-colored

tephriphonolitic lava flows and its volcaniclastics overlie paleosol, d, e green-colored coarse-grained lamproite lava from the dome showing onion-type skin weathering features, $\mathbf{f}$ flow lamination in phonotephrite lavas

At the Okkakaya Tepe and Göktepe locations, lava flows of lamproite crop out in a relatively large area. The lamproitic lava flows cover sedimentary rocks of the Tauride Belt and tephriphonolitic lava flows, covered by both leucitite volcaniclastic deposit and the products of trachyandesitic pyroclastic succession. Lamproitic lavas partly overlie the tephriphonolite lava flows at the Okkakaya. A small-volume lamproitic lava flow is emplaced and 
Fig. 7 Micrographic textures and mineralogical compositions of the volcanic rocks;

a melilite-leucitite,

b spotted trachyandesite,

c tephriphonolite,

d trachyandesite,

e coarse-grained massive

lamproite lava, f phonotephrite, $\mathbf{g}$ phonolite, $\mathbf{h}$ basaltic trachyandesite, $\mathbf{i}$ nosean-bearing trachyandesite. Abbreviations are given in Table 3
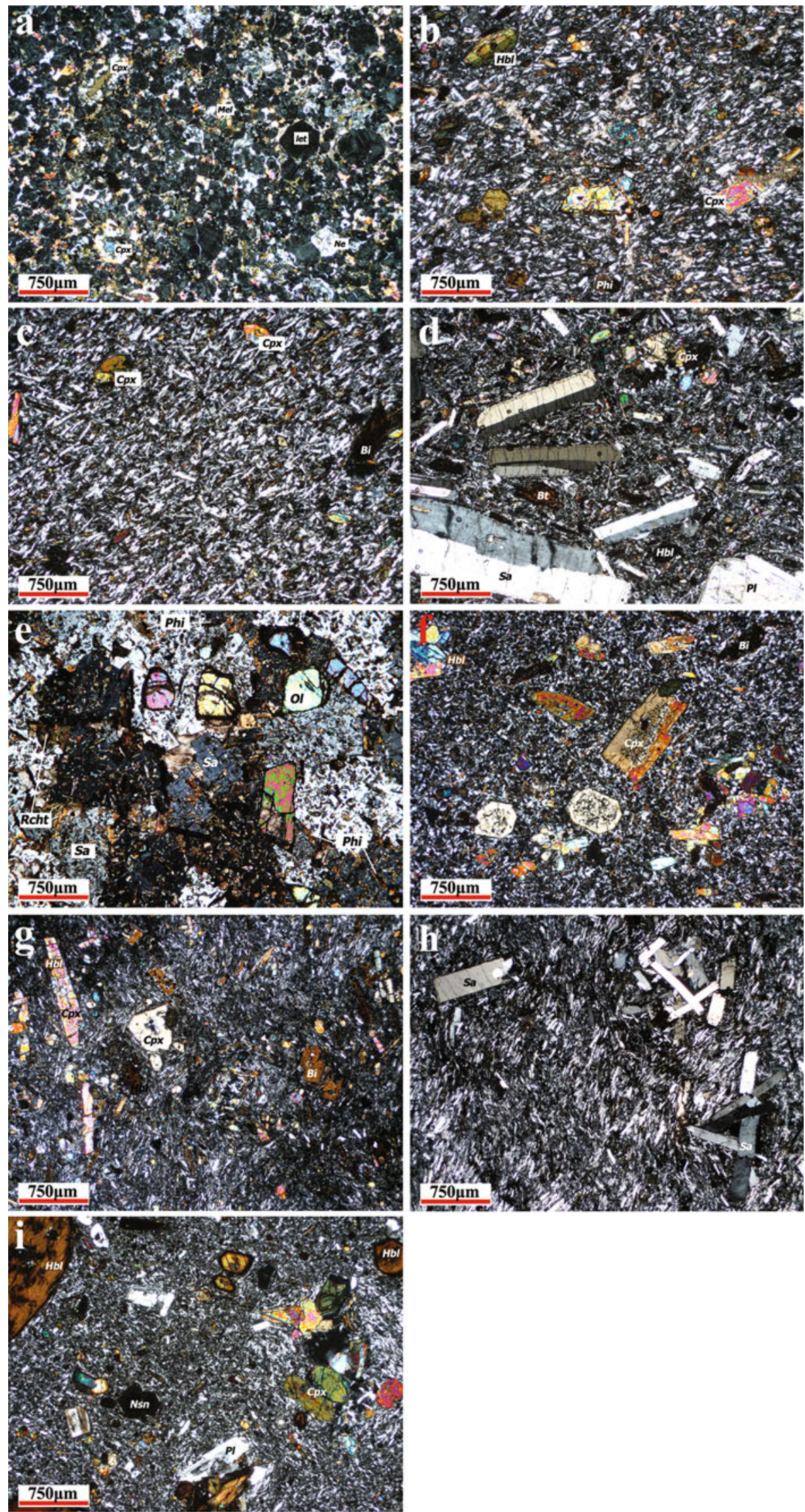

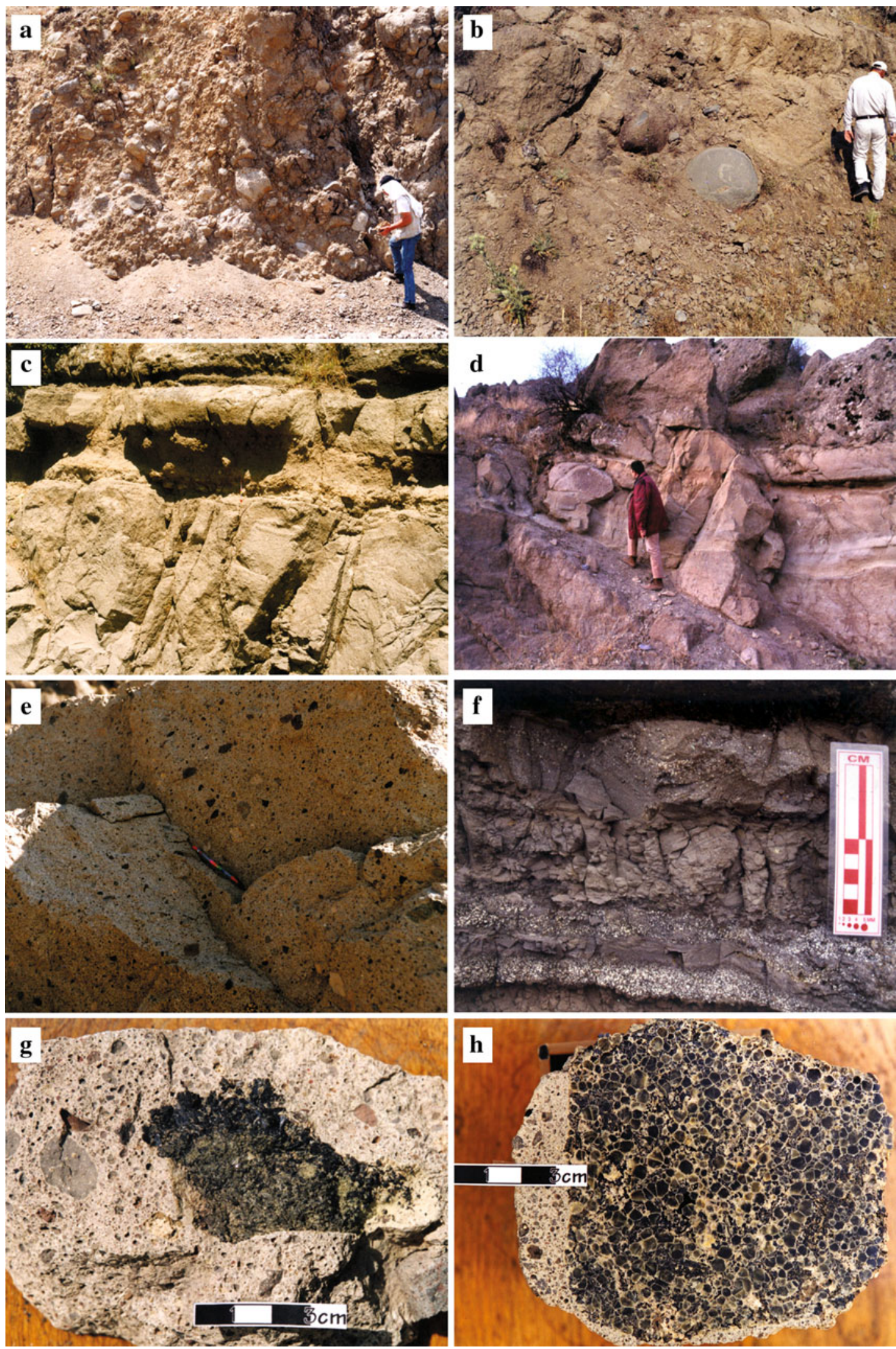

Fig. 8 Characteristic field views of proximal $(\mathbf{a})$, medial $(\mathbf{b}-\mathbf{e})$ and distal facies $(\mathbf{f})$ of leucitite volcaniclastic deposit; $\mathbf{g}$ phlogopite + clinopyroxene-rich cumulates in the volcaniclastic debris flow, $\mathbf{h}$ leucite + clinopyroxene + phlogopite + melanite cumulate in the deposit 
exposed at Mursalini (4 $\mathrm{km}$ away from İlyaslı village). A dyke is exposed near the Bahçegüney Tepe with less voluminous lava flows. In addition, the dome-like lamproite body is exposed between Aşağı İlyaslı and İlyaslı villages. At İlyasl1, the dome-like intrusion and smallvolume crystalline lamproitic magma intruded the flysch facies of the Tauride Belt where the early-stage products of trachyandesitic volcanism occur as ignimbrite and debris flow deposits. The lamproitic volcanism at Mursalini produced the lamproitic pyroclastic deposits, followed by lamproitic lava flows. These products overlie a trachyandesitic ignimbrite of the early-stage volcanism. The lamproitic lava flow intruded into unconsolidated wet trachyandesitic ignimbrite, which resulted in the characteristic feature of the peperitic breccia, jig-saw fitting vesicular lava fragments due to very rapid cooling of a lava lobe (Fig. 9a). The best-preserved lamproite lavas are found at the Okkakaya Tepe and Göktepe locations. Flow types are variable: massive, vesicular with flow lamination, flow breccias and fine-grained coherent lava flows. A typical individual lava flow may contain flow lamination with flow-foliated phlogopite phenocrysts and includes coarse- to medium-grained massive parts. In the massive part onion-type alterations are present (Fig. 6e). The lava breccias at the top contain vesicular texture with vesicles elongated in the flow direction. The crystallization age of the lamproites is $11.91 \pm 0.13 \mathrm{Ma}$ (age from phlogopite crystals from the sample "05IL03"; Table 2) and is essentially coeval with melilite-leucitites.

The leucitite volcaniclastic deposit is widespread in the south and central part of the study area, covering approximately $50 \mathrm{~km}^{2}$. The presence of abundant volcanic conglomerate consisting of angular to rounded leucitite lava cobbles and boulders up to two meters in diameter, and the absence of trachyandesitic volcanic fragments imply that the volcaniclastic deposit is probably related to large-scale leucitite-type activity, producing crystal fragment-rich sandy matrix. The characteristic feature of the leucitite volcaniclastic deposit is the presence of mafic mineral-rich cumulates which mainly have the following mineralogy: clinopyroxene, phlogopite, melanite, melilite, leucite, perovskite, ilmenite, spinel and apatite (Fig. 8g, h).

Based on internal stratigraphy and its sedimentary structures, the leucitite volcaniclastic deposit can be divided into three parts: proximal, medial and distal from southern side to northern side of the study area (Table 3).

(1) The proximal part of the volcaniclastic deposit is located in the southern part of the study area (probably close to vent area) and covers the limestone unit of the Tauride belt. It is characterized by a volcanic breccia formed by large angular to subrounded leucitite lava boulders and cobbles within sandy size matrix. The deposits are dominantly clast-supported, although grain-
Fig. 9 Characteristic field views of trachyandesitic pyroclastic succession; a lamproitic peperites in trachyandesitic ignimbrite, b disorganized pumice fragments, $\mathbf{c}$ flattened and glassy pumice fragments (fiamme) in trachyandesitic welded ignimbrites, $\mathbf{d}$ the photomicrograph of the trachyandesitic welded ignimbrite; flatted pumices can be distinguished by their dark color, e gas-escape pipes (elutriation pipes) developed in non-welded ignimbrite, $\mathbf{f}$ cross-bedding and wavy structure in the non-welded ignimbrite, $\mathbf{g}$ block-sag within surge deposits, h volcanic bombs within non-welded trachyandesitic ignimbrite

supported deposit is also subordinately observed (Fig. 8a). The fragments of volcanic breccia consist of monolithologic leucitite lava blocks, euhedral leucite, pyroxene, phlogopite crystals and metasomatic cumulates. The deposits are mainly disorganized and poorly sorted with lack of bedding; (2) the medial part is characterized by massive volcanic breccia/conglomerate and a massive to stratified volcaniclastic sandstone association. The main clast components of the deposit are leucitite lava fragments and leucite crystals that are subrounded and clast-supported in some levels of the deposit. The stratified volcaniclastic sandstone may show very planar, erosional contact and occasional channel structures at the base of volcanic breccia (Fig. 8b); (3) the distal deposits, where the volcaniclastic sandstone is massive, contains very sparse cobbles (Fig. 8c). The volcaniclastic sandstone laterally grades to distal deposits with up to 5-cm-thick sandstone showing normal grading (Fig. 8d, e). The following major features of the distal deposits distinguish them from the others deposits: (1) the presence of the matrix and the breccia forming are almost entirely grain supported, (2) the absence of very large boulders in the deposits and (3) the abundance of sand-sized fragments and their occasional stratification. The distal deposits extend into the northeastern part of the study area and consist of well-bedded sandstone composed of euhedral leucite crystals and minor leucitite lava fragments up to a few centimeters in diameter. Fine-grained volcaniclastic sandstone presents normal grading within individual layers that are rich up to $10 \mathrm{~cm}$ in thickness (Fig. 8f). The layers locally present erosional channel surfaces.

The inner volcano-stratigraphic and sedimentary structures of the overall volcanoclastic deposit indicate the extensive leucitite-type volcanic activity. Various clast components belonging to leucitite volcanism, gradual changes in stratification from disorganized to well-bedded layers, grain size distribution from coarse- to fine-grained facies and channel fill structures formed within medial and proximal deposits are major evidence for sedimentary reworking mechanism. The inner volcano-stratigraphy of the volcaniclastic debris flow deposit indicates that probable flow direction is from south to northeast in the study area. 

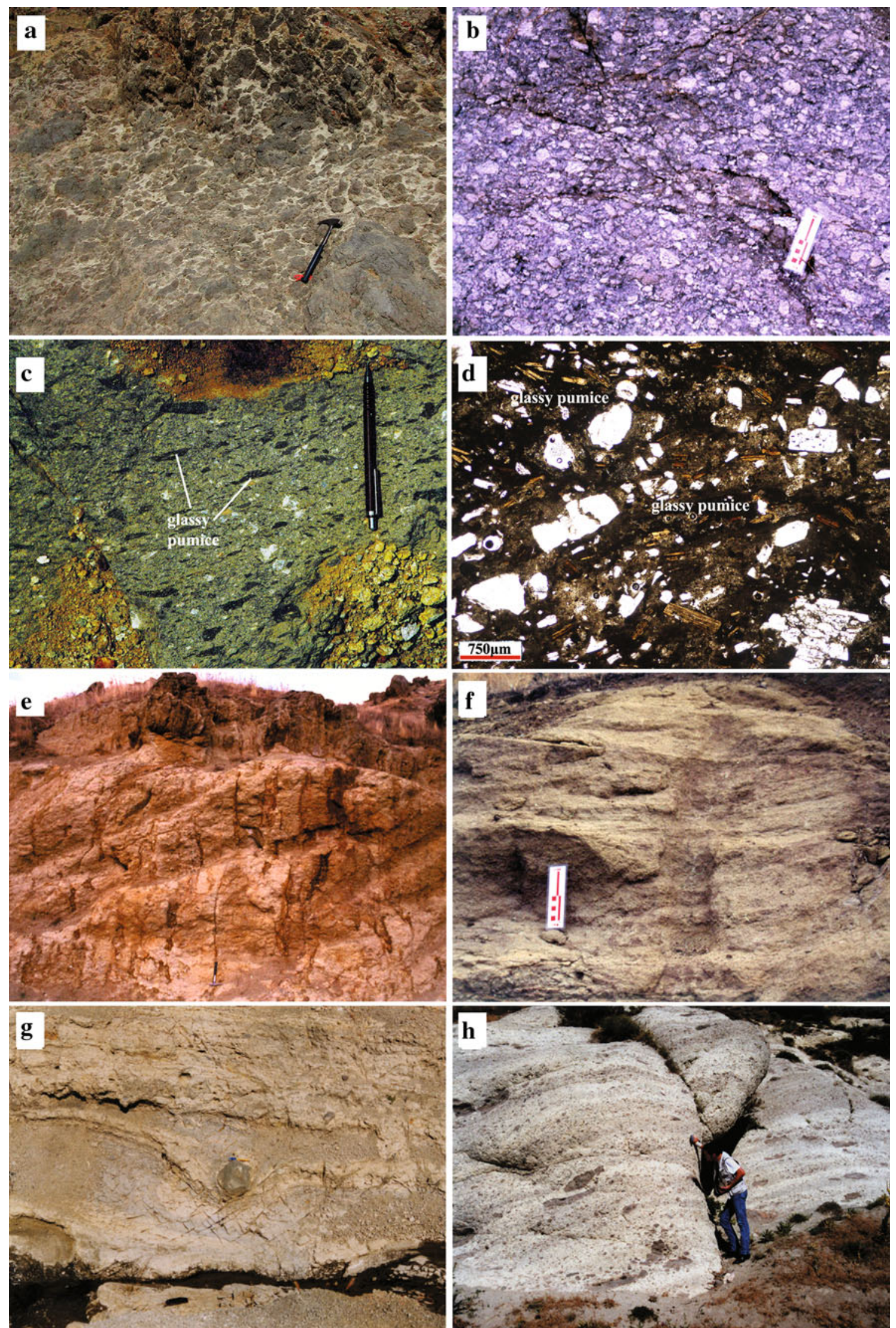


\section{Second episode of the late-stage volcanism}

Products belonging to the second-episode volcanic activity comprise a widespread trachyandesitic pyroclastic succession and late-stage lavas. The trachyandesitic volcanic rocks mainly overlie a leucitite volcaniclastic deposit at the southwestern part of the area (Fig. $4 \mathrm{a}-\mathrm{c}$ ). Phonotephritic ignimbrites that belong to third episode overlie the trachyandesitic late-stage succession (Fig. 4c, d). Massive, columnar jointed, rarely flow-banded trachyandesite lavas are pink-gray, gray-light gray and light brown colored, which are highly porphyritic (up to $20 \%$ phenocrysts). The thick and widespread trachyandesitic pyroclastic succession was produced by multistage volcanic events. It covers an area over $100 \mathrm{~km}^{2}$ and overlies the basement rocks of the Tauride Belt and leucitite volcaniclastic deposit (Figs. 3, 4). The trachyandesitic pyroclastic succession includes extensive pyroclastic flow deposits. The succession comprises extensive ignimbrite and associated surge and ash fall deposits accumulated near the probable vent system, where several trachyandesitic domes occur in the northwestern part of the area. The ignimbrite facies is characterized by a massive appearance and abundant equant pumice fragments (Fig. 9b).

The trachyandesitic ignimbrites occasionally show intense welding textures that are distinguished by aligned, flattened dark brown glassy pumice (fiamme) (Fig. 9c). In thin sections welded ignimbrites present distinctive compaction and planar foliation and flattened pumice (Fig. 9d). Welded ignimbrites present abrupt vertical transition to nonwelded trachyandesitic ignimbrite, which is distinguished by vertical gas-escape pipes (elutriation pipes) due to the compaction of the hot pyroclastic materials (Fig. 9e). The surge deposits are distinguished by cross-bedding and bomb-sag structures (Fig. 9f, g). The surge deposits are intercalated with ash falls and occasionally contain volcanic bombs (block-sag structures), indicating ballistic transport (Fig. 9h).

\section{Third episode of late-stage volcanism}

The third episode and the last volcanic activity in the study area produced phonotephritic, phonolitic, basaltic trachyandesitic and nosean-bearing trachyandesitic lava domes, dykes and flows. The products of phonotephritic volcanism are generally massive lava domes, lava flows and dykes cutting and covering the phonotephritic ignimbrites (Fig. 4c, d, f). Phonolitic, trachyandesitic and noseanbearing trachyandesite lavas cut and overlie the leucitite volcaniclastic deposit, lacustrine limestone and phonotephritic ignimbrite, respectively (Fig. 4a).

Phonotephrite domes and lava flows are widespread and crop out around the Killimatan Tepe (2,247 m), Göktepe $(1,973 \mathrm{~m})$, Karatepe $(1,686 \mathrm{~m})$ and Bahçegüney Tepe
$(1,460 \mathrm{~m})$. The lavas mainly extend about $8 \mathrm{~km}$ distance in a NE direction from the eruption centers located near Kilimatan Tepe (Fig. 4). The products of phonotephritic volcanism, which is one of the last volcanic phases of activity in the study area, are generally found as massive lava domes, lava flows and dykes, cutting and covering phonotephritic ignimbrite as seen from the stratigraphic sections (Fig. 4c-f). The main eruption centers of volcanism are located around the Killimatan Tepe and a small one around Karatepe, where lava domes and dykes can be distinguished. The thickness of the lava flows can reach up to $50 \mathrm{~m}$. Phonotephritic lava flows are mainly composed of gray-dark gray-colored massive and vesicular lavas with well-observed porphyritic textures in which the phenocrysts are mainly pyroxene, mica and rare hornblende. The upper part of the lava flows and outer surface of the blocks include weak flow foliation planes and irregular shaped vesicles. Flow banding is defined by light and dark gray thin laminations (Fig. 6f).

The products of the final phase of volcanic activity in the study area also produced a phonolitic and trachyandesitic lava dome, which are located around the Killimatan Tepe in the western part of the area (Fig. 4). The phonolitic lava dome forms the highest aspect morphology of Devkaya Tepe, which intrudes and overlies the leucitite volcaniclastic deposit, lacustrine limestone and phonotephritic ignimbrite, respectively. The phonolite lava dome has conical-shaped outcrop with $625 \mathrm{~m}$ width and $725 \mathrm{~m}$ length, whereas exposures of basaltic trachyandesite occur as small dome-shaped extrusion (about $150 \mathrm{~m}$ in diameter).

The phonolite is observed as a lava dome that laterally passes discontinues rubble lava flow. The phonolite dome has a porphyritic texture, and at the periphery, it passes into a glassy to fine-grained texture. At the northeastern flank of the Devkaya Tepe, basaltic trachyandesite lavas intrude the massive lava flows of the phonolite as small dome-like bodies as presenting a sharp contact with the phonolitic lavas. Trachyandesitic lavas do not show flow lamination, and their color is generally light gray to gray. Noseanbearing trachyandesite is exposed in the northwest of Yiprak village, toward the southern part of the study area. It forms a lava dome, with high relief morphology as a small hill on the flat surface of the basement being exposed in a limited area (125 m wide, $175 \mathrm{~m}$ length and approximately $40 \mathrm{~m}$ high). It cuts and covers leucitite volcaniclastic deposit.

Phonotephritic ignimbrite is the youngest volcanic product in the area. The ignimbrite mainly overlies the trachyandesitic pyroclastic succession and leucitite volcaniclastic deposit, but at the Devekaya Tepe and Killimatan Tepe, the sequence is underlain by shallow lacustrine (such as limestone) sedimentary rocks. Phonotephritic ignimbrite is exposed along the northeast flanks of the eruption 
centers, and the eruptive products cover approximately $21 \mathrm{~km}^{2}$ within the mapped area. The aerial distribution of the phonotephritic ignimbrite is estimated to be about $50 \mathrm{~km}^{2}$ or probably more. The succession is locally quite thick with an estimated average thickness of $150 \mathrm{~m}$, but depends upon topography and degree of erosion. The succession is $10-30 \mathrm{~m}$ thick in the distal parts, such as around Göktepe. The characteristic stratigraphic sections of the phonotephritic ignimbrite succession are well observed around Tokluk-Killimatan Tepe and Karatepe. The ignimbrite succession is composed of fine-grained clinopyroxene, plagioclase, sanidine crystal fragments and finegrained volcanic rock fragments, supported by a finegrained sandy and primary carbonate matrix.

The lower part of the phonotephritic ignimbrite is composed of reverse-graded pumice-rich and laminated volcanic sandstone-mud and silt alternations that are interbedded with shallow lacustrine sedimentary rocks (lacustrine limestone, marlstone). These deposits are overlain by volcanic sandstones with intercalated pumicebearing layers that are supported by a carbonate matrix. The base of the succession consists of massive non-graded, volcanic lithics, metamorphic clasts, abundant limestone clasts and a crystal fragment-rich level. The middle levels of the succession consist of fine-crystal fragments and finegrained limestone clast-bearing layers supported by a finegrained sandy matrix. This part of the succession is defined by crystal-rich, planar to low-angle cross-stratified layers and gas segregation structure-bearing layers.

\section{Summary and conclusions}

In summary, magmatism in the Afyon volcanic area in western Anatolia produced a temporal continuum from $\mathrm{Si}$-oversaturated to $\mathrm{Si}$-undersaturated products that mimic change from calc-alkaline to ultrapotassic character. Within the time range from around 14 to $12 \mathrm{Ma}$, Afyon volcanism shows temporal change coupled with geochemical variation, most specifically in terms of the extent of $\mathrm{Si}$ saturation. Our data show that the products of the early-stage (around $14 \mathrm{Ma}$ ) volcanics located around and more southward of the Afyon are completely Si oversaturated. The main change happened during voluminous volcanism, which shifted further southward away from Afyon city (Fig. 3) over three major volcanic episodes of latestage activity around $12 \mathrm{Ma}$. The first volcanic episode, corresponding to late-stage activity, was characterized by the emplacement of small lava domes and flows of melilite-leucitite, lamproite, spotted trachyandesite and tephriphonolite at the south of the Afyon volcanic province. The Si-oversaturated volcanics of the early-stage activity and the lamproitic lava flows of late-stage volcanic products (first episode) are covered by a leucitite volcaniclastic deposit. This volcanic episode was followed by trachyandesitic volcanism at the north of the volcanic province. The trachyandesitic volcanoes produced extensive pyroclastic flow deposits, extruded explosively due to the very high volatile content in magma. The succession was deposited from pyroclastic flows emplaced in subaerial and subaqueous environments.

The upper limit of the second-episode volcanism is constrained by the lacustrine sedimentary rocks overlying the trachyandesitic products. Lacustrine sedimentary rocks overlie both of the trachyandesitic pyroclastic succession and the leucitite volcaniclastic deposit. The lacustrine sediments gradationally interfinger with the phonotephritic ignimbrite belonging to the third- and last-episode volcanic activity of the Afyon volcanic province. The volcanic activity ended by the emplacement of phonotephritic, phonolitic, basaltic trachyandesitic and nosean-bearing trachyandesitic lava domes, dykes and flows, which cut and cover previous volcanic successions.

Acknowledgments We thank Ioan Seghedi and Hakan Çoban for constructive reviews that significantly improve the manuscript. The field work was financially supported by the Dokuz Eylül University Research Foundation (Project No. 0922.95.01.05) and Turkish Petroleum Corporation (TPAO).

Open Access This article is distributed under the terms of the Creative Commons Attribution License which permits any use, distribution, and reproduction in any medium, provided the original author(s) and the source are credited.

\section{References}

Agostini S, Ryan JG, Tonarini S, Innocenti F (2008) Drying and dying of a subducted slab: coupled $\mathrm{Li}$ and $\mathrm{B}$ isotope variations in western Anatolia Cenozoic Volcanism. Earth Planet Sci Lett 272:139-147

Agostini S, Doglioni C, Innocenti F, Manetti P, Tonarini S (2010) On the geodynamics of the Aegean rift. Tectonophysics 488:7-21

Akal C (2003) Mineralogy and geochemistry of melilite leucitites, Balçıkhisar, Afyon; Turkey. Turk J Earth Sci 12:215-239

Akal C (2008) K-richterite-olivine-phlogopite-diopside-sanidine lamproites from the Afyon Volcanic Province, Turkey. Geol Mag 145:1-16

Akal C, Helvacı C (2000) Leucitites around Balçıkhisar-Şuhut (Afyon/ Turkey). IESCA-2000, 25-29 Sept 2000, İzmir, Abstracts Book, p 118

Aldanmaz E, Pearce JA, Thirlwall MF, Mitchell JG (2000) Petrogenetic evolution of late Cenozoic, post-collision volcanism in western Anatolia, Turkey. J Volcanol Geotherm Res 102:67

Alıcı P, Temel A, Gourgaud A, Kieffer G, Gündoğdu MN (1998) Petrology and geochemistry of potassic rocks in the Gölcük area (Isparta, SW Turkey): genesis of enriched alkaline magmas. J Volcanol Geotherm Res 85:423-446

Aydar E, Bayhan H, Zimitoğlu O (1996) Investigation of volcanological and petrological evolution of Afyon stratovolcano. 
Yerbilimleri (Bull Earth Sci Appl Res Cent Hacettepe Univ) 18:87-107

Aydar E, Bayhan H, Gourgaud A (1998) Köroğlu caldera, mid-west Anatolia, Turkey: volcanological and magmatological evolution. J Volcanol Geotherm Res 85:83-98

Aydar E, Bayhan H, Gourgaud A (2003) The lamprophyres of Afyon stratovolcano, western Anatolia, Turkey: description and genesis. Geoscience 335:279-288

Besang C, Eckhardt FJ, Harre W, Kreuzer H, Müller P (1977) Radiometrische altersbestimmungen an neogenen eruptivgesteinen der Türkei. Geol Jahrb B 25:3-36

Biryol BC, Beck SL, Zandt G, Özacar AA (2011) Segmented African lithosphere beneath the Anatolian region inferred from teleseismic P-wave tomography. Geophys J Int 184:1037-1057

Borsi J, Ferrara G, Innocenti F, Mazzuoli R (1972) Geochronology and petrology of recent volcanics in the eastern Aegean Sea (West Anatolia and Lesvos Iceland). Bull Volcanol 36:473-496

Bozkurt E (2001) Neotectonics of Turkey - a synthesis. Geodin Acta $14: 3-30$

Bozkurt E (2003) Origin of NE-trending basins in western Turkey. Geodin Acta 16:61-81

Bozkurt E, Mittwede SK (2005) Introduction: evolution of continental extensional tectonics of western Turkey. Geodin Acta 18:153165

Çemen I, Catlos EJ, Göğüş O, Özerdem C (2006) Post-collisional extensional tectonics and exhumation of the Menderes Massif in the Western Anatolia Extended Terrane, Turkey. In: Dilek Y (ed) Postcollisional tectonics and magmatism in the Eastern Mediterranean Region: GSA's Spec Publ 409, pp 353-379

Çoban H, Flower MFJ (2006) Mineral phase compositions in silicaundersaturated 'leucite' lamproites from the Bucak area, Isparta, SW Turkey. Lithos 89:275-299

Çoban H, Flower MFJ (2007) Late Pliocene lamproites from Bucak, Isparta (southwestern Turkey): implications for mantle 'wedge' evolution during Africa-Anatolian plate convergence. J Asian Earth Sci 29:160-176

Dalrymple GB, Duffield WA (1988) High precision ${ }^{40} \mathrm{Ar} /{ }^{39} \mathrm{Ar}$ dating of Oligocene rhyolites from the Mogollon-Datil volcanic field using a continuous laser system. Geophys Res Lett 15:463-466

Dilek Y, Altunkaynak S (2007) Cenozoic crustal evolution and mantle dynamics of post-collisional magmatism in western Anatolia. Int Geol Rev 49:431-453

Ercan E, Satır M, Sevin D, Türkecan A (1996) Some new radiometric ages from tertiary and quaternary volcanic rocks from West Anatolia (in Turkish with English abstract). Mineral Res Explor Bull Turk 119:103-112

Ercan T, Türkecan A, Satır M (2000) Neogene volcanism of Karaburun Peninsula (in Turkish with English abstract). Cumhuriyetin 75. Yıldönümü Yerbilimleri ve Madencilik Kongresi. Mineral Res Expl Bull Turk, pp 1-18

Erdoğan B, Uchman A, Güngör T, Özgül N (2004) Lithostratİgraphy of the Lower Cambrian metaclastics and their age based on trace fossils in the Sandiklı region, southwestern Turkey. Geobios Lyon 38:346-360

Erkül F, Helvacı C, Sözbilir H (2005) Evidence for two episodes of volcanism in the Bigadiç borate basin and tectonic implications for western Turkey. Geol J 40:545-570

Ersoy Y, Helvacı C, Sözbilir H, Erkül F, Bozkurt E (2008) A geochemical approach to Neogene-Quaternary volcanic activity of western Anatolia: an example of episodic bimodal volcanism within the Selendi Basin, Turkey. Chem Geol 255:265-282

Ersoy Y, Helvac1 C, Palmer MR (2010a) Mantle source characteristics and melting models for the early-middle Miocene mafic volcanism in western Anatolia: implications for enrichment processes of mantle lithosphere and origin of K-rich volcanism in postcollisional settings. J Volcanol Geotherm Res 198:112-128
Ersoy Y, Helvacı C, Sözbilir H (2010b) Tectono-stratigraphic evolution of the NE-SW-trending superimposed Selendi basin: implications for late Cenozoic crustal extension in western Anatolia, Turkey. Tectonophysics 488:210-232

Faccenna C, Piromallo C, Crespo-Blanc A, Jolivet L, Rossetti F (2004) Lateral slab deformation and the origin of the western Mediterranean arcs. Tectonics 23:TC1012

Floyd PA, Castillo PR (1992) Geochemistry and petrogenesis of Jurassic ocean crust basalt, ODP Leg 129, Site 801. In: Larson R, Launcelot $\mathrm{Y}$ et al (eds) Proceedings of ODP science results, vol 129, pp 361-388

Floyd PA, Helvac1 C, Mittwede SK (1998) Geochemical discrimination of volcanic rocks associated with borate deposits: an exploration tool? J Geochem Explor 60:185-205

Francalanci L, Innocenti F, Manetti P, Savaşçın MY (2000) Neogene alkaline volcanism of the Afyon-Isparta area, Turkey: petrogenesis and geodynamic implications. Mineral Petrol 70:285-312

Glodny J, Hetzel R (2007) Precise U-Pb ages of syn-extensional Miocene intrusions in the central Menderes Massif, western Turkey. Geol Mag 144:235-246

Göncüoğlu MC (1997) Distribution of Lower Paleozoic units in the Alpine Terranes of Turkey: paleogeographic constraints In: Göncüoğlu MC, Derman AS (eds) Lower Paleozoic evolution in northwest Gondwana, Turkish Assoc Petrol Geol Spec Publ 3, pp 13-24

Göncüoğlu MC, Kozlu H (2000) Early Paleozoic evolution of the NW Gondwanaland: data from southern Turkey and surrounding regions. Gondwana Res 3:315-323

Gündoğan İ, Yücel-Öztürk Y, Helvacı C, Güngör T, Karamanderesi İH, Koralay OE (2012) Geological setting of Sandıklı (Afyon) volcanics and geochronological signature of the Karacaören syenitoid in volcanic succession. In: 65th Geological Congress of Turkey, Ankara (Abstracts Book), p 363

Güngör T (2006) Deformation of the Lower Cambrian sequence in the Sandiklı region (Afyon), central Turkey. Geodin Acta 19(5):345-361

Gürsu S, Göncüoğlu MC (2006) Petrogenesis and tectonic setting of Late Pan-African meta-felsic rocks in Sandiklı area (western Turkey). Int J Earth Sci 95:741-757

Gürsu S, Göncüoğlu MC (2007) Comments on "deformation of the Lower Cambrian sequence in the Sandiklı Region (Afyon), central Turkey" by T. Güngör. Geodin Acta 20(5):353-362

Helvac1 C, Alonso RN (2000) Borate deposits of Turkey and Argentina: a summary and geological comparison. Turk J Earth Sci 24:1-27

Helvacı C, Ersoy EY, Sözbilir H, Erkül F, Sümer Ö, Uzel B (2009) Geochemistry and ${ }^{40} \mathrm{Ar} /{ }^{39} \mathrm{Ar}$ geochronology of Miocene volcanic rocks from the Karaburun Peninsula: implications for amphibole-bearing lithospheric mantle source, western Anatolia. J Volcanol Geotherm Res 185:181-202

Innocenti F, Agostinia TS, Di Vincenzo, Doglionic GC, Manetti P, Savaşçın MY, Tonarini S (2005) Neogene and quaternary volcanism in western Anatolia: magma sources and geodynamic evolution. Mar Geol 221:397-421

Irvine TN, Baragar WRA (1971) A guide to the chemical classification of the common volcanic rocks. Can J Earth Sci 8:523-548

Işık V, Tekeli O, Seyitoğlu G (2004) The ${ }^{40} \mathrm{Ar} /{ }^{39} \mathrm{Ar}$ age of extensional ductile deformation and granitoid intrusion in the northern Menderes core complex: implications for the initiation of extensional tectonics in western Turkey. J Asian Earth Sci 23:555-566

Karaoğlu Ö, Helvacı C, Ersoy Y (2010) Petrogenesis and ${ }^{40} \mathrm{Ar} /{ }^{39} \mathrm{Ar}$ geochronology of the volcanic rocks of the Usak-Güre basin, western Türkiye. Lithos 119:193-210

Kumral M, Çoban H, Gedikoğlu A, Kılınç A (2006) Petrology and geochemistry of augite trachytes and porphyritic trachytes from 
the Gölcük volcanic region, Isparta, SW Turkey: a case study. J Asian Earth Sci 27:707-716

Le Bas MJ, Le Maitre RW, Streckeisen A, Zanettin B (1986) A chemical classification of volcanic rocks based on the total alkali-silica diagram. J Petrol 27:745-750

Lefèvre C, Bellon H, Poisson A (1983) Présence de leucitites dans le volcanism Pliocene de la region d'Isparta (Taurides occidentales, Turquie). CR Acad Sci IIA 297:367-372

MTA Geological Map of Turkey (1:500 000) (2002) Publication of Mineral Research and Exploration Institute of Turkey

Okay A, Tüysüz O (1999) Tethyan sutures of northern Turkey. In: Durand B, Jolivet L, Horvath F and Seranne M (eds) The Mediterranean Basins: tertiary extension within the Alpine Orogen. Geol Soc Lond Spec Publ 156, pp 475-515

Özgül N (1984) Stratigraphy and tectonics evolution of the central Taurides. In: Tekeli O, Göncüoğlu MC (eds) Geology of the Taurus belt. Proceedings of the international Tauride symposium, Mineral Research and Exploration Institute of Turkey (MTA) Publication, pp 77-90

Paton SM (1992) The relationship between extension and volcanism in western Turkey, the Aegean Sea, and central Greece, Ph.D. thesis, Cambridge University

Peccerillo A (2003) Plio-quaternary magmatism in Italy. Episodes 26:222-226

Pişkin Ö (1980) Kadıkalesi-Girelbelen (Bodrum yarımadası) hidrotermal ve kontakt metasomatik $\mathrm{Pb}, \mathrm{Zn}, \mathrm{Cu}$ cevherleşmelerinin mineralojik ve jeolojik incelenmesi. Doçentlik Tezi. Ege University, İzmir

Poisson A, Akay E, Dumont JF, Uysal Ş (1984) The Isparta Angle: a Mesozoic paleorift in the western Taurides In: Tekeli O, Göncüoğlu MC (eds) Geology of the Taurus belt. Proceedings of the international Tauride symposium, Mineral Research and Exploration Institute of Turkey (MTA) Publication, pp 11-26

Prelević D, Akal C, Foley SF, Romer RL, Stracke A, van Den Bogaard P (2012) Ultrapotassic mafic rocks as geochemical proxies for postcollisional mantle dynamics of lithosphere: the case of SW Anatolia-Turkey. J Petrol 53:1019-1055

Purvis M, Robertson AHF, Pringle M (2005) $\mathrm{Ar}^{40}-\mathrm{Ar}^{39}$ dating of biotite and sanidine in tuffaceous sediments and related intrusive rocks: implications for the Early Miocene evolution of the Gördes and Selendi basins, W Turkey. Geodin Acta 18:239-254

Rimmelé G, Oberhänsli R, Goffé B, Jolivet L, Candan O, Çetinkaplan M (2003) First evidence of high-pressure metamorphism in the 'Cover Series' of the southern Menderes Massif. Tectonic and metamorphic implications for the evolution of SW Turkey. Lithos 71:19-46

Ring U, Collins AS (2005) U-Pb SIMS dating of synkinematic granites: timing of core-complex formation in the northern Anatolide belt of western Turkey. J Geol Soc Lond 162:289-298

Robert U, Montigny R (2001) A new age data set for the Bodrum volcanic complex (SW Anatolia). Fourth international Turkish geology symposium, Adana, Turkey, 303 pp
Robert U, Foden J, Varne R (1992) The Dodecanese Province, SE Aegean: a model for tectonic control on potassic magmatism. Lithos 28:241-260

Şengör AMC, Yilmaz Y (1981) Tethyan evolution of Turkey: a tectonic approach. Tectonophysics 75:181-241

Şengör AMC, Satır M, Akkök R (1984) Timing of tectonic events in the Menderes Massif, western Turkey: implications for tectonic evolution and evidence for Pan-African basement in Turkey. Tectonics 3:693-707

Şengör AMC, Görür N, Saroğlu F (1985) Strike-slip faulting and related basin formation in zones of tectonic escape: Turkey as a case study. In: Biddle KT, Christie-Blick N (eds) Strike-slip deformation, basin formation, and sedimentation. Soc Econ Paleontol Mineral Spec Publ 37, pp 227-264

Seyitoğlu G, Scott BC (1996) The cause of N-S extensional tectonics in western Turkey: tectonic escape vs back-arc spreading vs orogenic collapse. J Geodyn 22:145-153

Seyitoğlu G, Anderson D, Nowell G, Scott B (1997) The evolution from Miocene potassic to Quaternary sodic magmatism in western Turkey: implications for enrichment processes in the lithospheric mantle. J Volcanol Geoth Res 76:127-147

Spakman W, Wortel MJR, Vlaar NJ (1988) The Hellenic subduction zone: a tomographic image and its geodynamic implications. Geophys Res Lett 15:60-63

Sunder MS (1980) Geochemistry of Sarıkaya borate deposits (KırkaEskişehir). Bull Geol Congr Turk 2:19-34

Thompson RN (1997) Primary basalts and magma genesis. III. Alban Hills, Roman Comagmatic Province, central Italy. Contrib Mineral Petrol 55:1-31

Van den Bogaard $\mathrm{P}(1995){ }^{40} \mathrm{Ar} /{ }^{39} \mathrm{Ar}$ ages of sanidine phenocrysts from Laacher See Tephra (12,900 yr BP): chronostratigraphic and petrological significance. Earth Planet Sci Lett 133:163-174

van Hinsbergen DJJ, Kaymakcı N, Spakman W, Torsvik TH (2010) Reconciling the geological history of western Turkey with plate circuits and mantle tomography. Earth Planet Sci Lett 297:674-686

Westaway R (2006) Cenozoic cooling histories in the Menderes Massif, western Turkey, may be caused by erosion and flat subduction, not low-angle normal faulting. Tectonophysics 412:1-25

Westaway R, Guillou H, Yurtmen S, Demir T, Scaillet S, Rowbotham $G$ (2005) Investigation of the conditions at the start of the present phase of crustal extension in western Turkey, from observations in and around the Denizli region. Geodin Acta 18:209-238

Wortel MJR, Spakman W (2000) Subduction and slab detachment in the Mediterranean-Carpathian region. Science 290:1910-1917

Yılmaz Y, Genç SC, Gürer F, Bozcu M, Yılmaz K, Karacık Z, Altunkaynak Ş, Elmas A (2000) When did the western Anatolian grabens begin to develop? Geol Soc Lond Spec Publ 173, pp 353-384

Yoder HS, Tilley CE (1962) Origin of basalt magmas. J Petrol $3: 343-532$ 